\title{
Methyl gallate and chemicals structurally related to methyl gallate protect human umbilical vein endothelial cells from oxidative stress
}

Wan Kyunn Whang ${ }^{1}$, Hyung Soon Park ${ }^{2}$, InHye Ham ${ }^{1}$, Mihyun $\mathrm{Oh}^{1}$, Hong Namkoong ${ }^{3}$, Hyun Kee $\mathrm{Kim}^{3}$, Dong Whi Hwang ${ }^{2}$, Soo Young Hur ${ }^{4}$, Tae Eung $\mathrm{Kim}^{4}$, Yong Gyu Park ${ }^{5}$, Jae-Ryong Kim ${ }^{6}$ and Jin Woo Kim ${ }^{3,4,7}$

\author{
${ }^{1}$ College of Pharmacy, Chung-Ang University \\ 221 Heukseok-dong, Dongjak-gu, Seoul 156-755, Korea \\ ${ }^{2}$ KeyGene Life Science Institute \\ KeyGene Science, Corp \\ Ansan, Gyeonggi-do 425-791, Korea \\ ${ }^{3}$ Laboratory of Molecular Genetics \\ Research Institute of Medical Science \\ ${ }^{4}$ Department of Obstetrics and Gynecology \\ ${ }^{5}$ Department of Biostatistics College of Medicine \\ The Catholic University of Korea \\ Seoul 137-040, Korea \\ ${ }^{6}$ Department of Biochemistry and Molecular Biology \\ Aging-assoiciated Vascular Disease Research Center \\ College of Medicine, Yeungnam University \\ Daegu 705-717, Korea \\ ${ }^{7}$ Corresponding author: Tel, 82-2-590-2389; \\ Fax, 82-2-593-2389; E-mail, jinwoo@catholic.ac.kr
}

Accepted 14 July 2005

Abbreviations: CAT, catalase; DCFH-DA, 2',7'-dichlorodihydrofluorescein-diacetate; DDRT-PCR, differential display reverse transcription-PCR; EGCG, (-)-epigallocatechin gallate; GPX, glutathione peroxidase; HUVECs, Human umbilical vein endothelial cells; LDL, low density lipid; LPO, lipid peroxidation; MDA, malondialdehyde; meGAL, methyl gallate; RNS, reactive nitrogen species; ROS, reactive oxygen species; SOD, superoxide dismutase

\footnotetext{
Abstract

Methyl gallate (meGAL) is known as one of major antioxidants. To investigate whether meGAL protects human cells from oxidative stress, meGAL extracted from Korean medicinal plant, Cercis chinensis leaves, was primarily screened using cell viability assay against oxidative stress. Human umbilical vein endothelial cells (HUVECs) were treated with three different concentrations of meGAL
}

for indicated time. After or during meGAL treatment, $\mathrm{H}_{2} \mathrm{O}_{2}$ was added and incubated. meGAL showed free radical scavenging effect at low concentration $\mathbf{( 0 . 0 2}$ $\mathrm{mM}$ ) and cell protective effect against $\mathrm{H}_{2} \mathrm{O}_{2}$-mediated oxidative stress. meGAL recovered viability of HUVECs damaged by $\mathrm{H}_{2} \mathrm{O}_{2}$-treatment, reduced the lipid peroxidation (LPO) and decreased the internal reactive oxygen species (ROS) level elevated by $\mathrm{H}_{2} \mathrm{O}_{2}$-treatment. Free radical scavenging effect of meGAL was proven to be very high. Differential display reverse transcription-PCR analysis showed that meGAL upregulated the levels of regulator of chromatin condensation 1, type 1 sigma receptor and phosphate carrier protein expressions, respectively. Based on structural similarity compared with meGAL, 14 chemicals were chosen and viability assay was performed. Four chemicals, haematom mic acid ( $56.2 \%$ enhancement of viability), gallic acid $(35.0 \%)$, methylorsellinic acid $(23.7 \%)$, and syringic acid $(20.8 \%)$, enhanced more potent cell viability than meGAL, which showed only $18.1 \%$ enhancement of cell viability. These results suggest that meGAL and four meGAL-related chemicals protect HUVECs from oxidative stress.

Keywords: gallic acid; hydrogen peroxide; methyl gallate; oxidative stress; plant, medicinal; syringic acid

\section{Introduction}

ROS and reactive nitrogen species (RNS) constantly generated in normal condition by aerobic metabolism include free radicals such as superoxide anion, hydroxyl radicals, nonradical hydrogen peroxide, peroxinitrite, nitroxyl anion and nitric oxide (Beckman and Ames, 1998; Curtin et al., 2002; Droge, 2002). In normal biological systems, redox homeostasis is maintained by controlling the balance between ROS production and various types of scavengers called antioxidants. Transient changes in oxidants-antioxidant balance are normally regulated by changing the production of counter species and reached to the steady-state over time (Shuli et al., 1991; Nakamura et al., 1994; Adler et al., 1999; Zhang and Storz, 2000; Droge, 2002). The persistent production of abnormally large amount of ROS or RNS, however, 
may lead to persistent changes in signal transduction and gene expression, which in turn may give rise to certain diseases.

meGAL is known as one of major antioxidants (Westenburg et al., 2000; Galato et al., 2001; Cho et al., 2003; Sohi et al., 2003). meGAL is a phytochemical from various species including Meliaceae, Rosa Rugosa and Galla Rhois, and its derivative (-)-epigallocatechin gallate (EGCG) is a major pytochemical of green tea, well known antioxidative beverage (Chen and Zhang, 2003). The radical scavenging effect and inhibition of LPO have been reported as major activities of meGAL (Westenburg et al., 2000; Galato et al., 2001; Cho et al., 2003). In addition, meGAL possesses the biological activities including antiplatelet activity (Lim et al., 2004), protection of DNA damaging against oxidative stress (Hsieh et al., 2004), protection of lung injury induced by phosgene (Sciuto and Moran, 2001), attenuation of diabetic oxidative stress (Cho et al., 2004) and antiapoptotic activity (Sohi et al., 2003). However, radical scavenging ability of meGAL has been a main focus to explain its protective function against oxidative stress.

The endothelium is known to be sensitive to injury caused by ROS (Valen et al., 1999), and in contrast, free radicals released by endothelial cells mediate the oxidation of low density lipid (LDL) (Zapolska-Downar et al., 1999). HUVECs have been used to study oxidative stress related researches and oxidative stress mediated by $\mathrm{H}_{2} \mathrm{O}_{2}$ damages cellular functions of HUVECs via various mechanisms (Valen et al., 1999; Estrada-Garcia et al., 2002; Waxman et al., 2003).

Various enzymatic and non-enzymatic self defense systems against oxidative stress including transiently over-produced ROS inside cells or exposure to external ROS inducing species have been identified and studied extensively. Catalase (CAT), SOD, and glutathione peroxidase (GPX) are the examples of enzymatic defense systems and non-enzymatic systems include tocopherol, ascorbate, urate and glutathione (Sies, 1993).

In the present study, we investigated cellular protective activity of meGAL under oxidative stress, identified genes expressed differentially by meGAL treatment and compared antioxidant effect of meGAL with its structurally related chemicals.

\section{Materials and Methods}

\section{Chemicals}

meGAL was extracted from Cercis chinensis leaves, purified and characterized as described (Kizu and Tomimori, 2003). meGAL (gallicin) was isolated from $2 \mathrm{~kg}$ of Cercis chinensis leaves. Dried leaves of the plants were extracted with methanol. The methanol extract was suspended with water and subsequently partitioned with ether. With $45 \mathrm{~g}$ of ether layer, Sephadex LH-20 column chromatography was repeatedly operated and finally $4.2 \mathrm{~g}$ of pure compound was obtained. Ethanol was used as a developing solvent. The structure of compound was elucidated by spectroscopic parameters of ${ }^{1} \mathrm{H}-\mathrm{NMR},{ }^{13} \mathrm{C}-\mathrm{NMR}$, FT-IR and FAB-MS, and identified as meGAL.

\section{HUVEC culture}

Cells were isolated from umbilical cords during full-term delivery. Patient consent was obtained from each individual and the use of tissue samples was approved by the ethics committee of our institution. Veins were cannulated and flushed first with PBS $\left(170 \mathrm{mM} \mathrm{NaCl}, 10 \mathrm{mM} \mathrm{Na} \mathrm{HPO}_{4}, 3.3 \mathrm{mM} \mathrm{KCl}\right.$, and $1.8 \mathrm{mM} \mathrm{KH}_{2} \mathrm{PO}_{4}, \mathrm{pH} 7.4$ ) before being filled with $0.2 \%$ (v/v) collagenase type II (Sigma, St. Louis, MO) in phosphate-buffered saline (PBS). Following $10 \mathrm{~min}$ incubation at $37^{\circ} \mathrm{C}\left(5 \% \mathrm{CO}_{2}\right)$, the collagenase was removed by flushing with $\mathrm{M}-199$ medium, and cells were centrifuged for $10 \mathrm{~min}$ at $1,000 \mathrm{~g}$. Cells were then resuspended in growth medium (M-199) and seeded into $25-\mathrm{cm}^{2}$ cell cultured flask previously coated with $1 \%(\mathrm{v} / \mathrm{v})$ liquid gelatin (Sigma) with PBS. Cells were grown to confluence before starting the treatments.

\section{Cell viability assay}

HUVECs were grown in 96-well micro plates in a final volume of $100 \mu$ culture medium containing $10^{4}$ cells per well. After allowing the cultures to grow to confluence, chemical and $\mathrm{H}_{2} \mathrm{O}_{2}$ treatments were followed with certain intervals. To determine the cell viability, XTT assay kit was used as described in company's manual (R\&D Systems Inc., Minneapolis, $M N)$. Two cases of oxidative stress were applied to pre-incubated HUVECs with chemical for $1 \mathrm{~h}$ : the treatment with $1 \mathrm{mM} \mathrm{H}_{2} \mathrm{O}_{2}$ for $1 \mathrm{~h}$ and the treatment with $0.1 \mathrm{mM} \mathrm{H}_{2} \mathrm{O}_{2}$ for $48 \mathrm{~h}$. Concentrations of chemical were varied from 0 to $0.5 \mathrm{mM}$.

\section{CAT activity}

CAT activity was determined using Oxis Research kit (OXISResearch, Portland, OR). After addition of 10 $\mathrm{mM} \mathrm{H} \mathrm{O}_{2}$, cell lysates were incubated for $1 \mathrm{~min}$ and mixed with chromogen substrate followed by addition of stopping reagent. Developed color for $10 \mathrm{~min}$ incubation was detected at $520 \mathrm{~nm}$. The rate of change in absorbance was converted to units of enzyme activity, determined from a standard curve using CAT. Enzyme activity was then standardized to $\mathrm{mg}$ protein. 


\section{SOD enzymatic activity}

SOD enzymatic activity was determined using the assay described in Oxis research SOD-525 kit manual (OXISResearch, Portland, OR). In brief, cell lysates were treated with mercaptan eliminating reagent and chromogenic substrate of SOD was added to the samples. SOD activity was determined by measuring the absorbance at $525 \mathrm{~nm}$ over time.

\section{Lipid peroxidation assay}

The extent of lipid peroxidation was determined by using the assay described in Oxis research LPO-586 kit manual (OXISResearch, Portland, OR). In brief, the LPO-586 assay is based on the reaction of a chromogenic reagent, $\mathrm{N}$-methyl-2-phenyliindole with malondialdehyde (MDA) and 4-hydroxyalkenals at $45^{\circ} \mathrm{C}$. One molecule of either MDA or 4-hydroxyalenal reacts with 2 molecules of reagent, N-methyl-2phenyliindole, to yield a stable chromophore with maximal absorbance at $586 \mathrm{~nm}$.

\section{Determination of intracellular ROS}

Intracellular ROS levels were determined by ROS mediated conversion of non-fluorescent 2',7'-dichlorofluorescein diacetate (DCFH) to DCF. The study was performed by slight modification of a method described previously (Zapolska-Downar et al., 1999). Cells were cultured overnight in 6-well culture plates and preincubated with meGAL for $1 \mathrm{~h}$. Next, $1 \mathrm{mM}$ of $\mathrm{H}_{2} \mathrm{O}_{2}$ was added to the cells and the cells were incubated for $1 \mathrm{~h}$. The cells were washed with M-199 media twice and followed by incubation with $0.02 \mathrm{mM}$ DCFH for $30 \mathrm{~min}$ in the dark. After incubation, 3 times of washing and lysis of the cells with $0.1 \%$ Triton $\mathrm{X}-100$ in $0.1 \mathrm{M}$ Tris was carried out. Relative fluorescence intensity of DCF at an emission of $525 \mathrm{~nm}$ and an excitation of $475 \mathrm{~nm}$ of each sample was measured using Victor $\mathrm{V}^{3}$ (Perkin-Elmer).

\section{Free radical scavenging capacity}

1,1-diphenyl-3-picrylhydrazyl (DPPH) radical has a deep violet color due to its unpaired electron and radical scavenging can be followed spectrophotometrically by the loss of absorbance at $517 \mathrm{~nm}$ as the pale yellow non-radical form is produced. $0.08 \mathrm{mM}$ of DPPH solution in ethanol was prepared and added to various concentrations of chemicals in ethanol. Absorbance changes at $517 \mathrm{~nm}$ for $10 \mathrm{~min}$ with $10 \mathrm{~s}$ of interval were monitored.

\section{Differential display reverse transcription- polymerase chain reaction (DDRT-PCR)}

For DD of mRNA (Liang and Pardee, 1992), HUVECs were obtained from full-term placenta after delivery. Patient consent was obtained from each individual and the use of tissue samples was approved by the ethics committee of our institution. Total RNA was extracted from HUVECs treated with or without 0.2 $\mathrm{mM}$ of meGAL for $8 \mathrm{~h}$ using an RNA extraction kit (RNeasy total RNA kit; Qiagen Inc., Valencia, CA) and $0.2 \mu \mathrm{g}$ of total RNA was used to generate cDNA in a reverse transcription reaction (RNAimage ${ }^{\mathrm{TM}} \mathrm{kit}$, GenHunter, MA). With the use of the differential display kit (RNAimage ${ }^{\mathrm{TM}}$ kit), we performed PCR using oligo-dT primers and arbitrary sequences, each 13 bases in length according to the manufacturer's recommendations. After cDNAs of $3^{\prime}$ termini of mRNAs were generated, the PCR products were separated by electrophoresis on a $6 \%$ denaturing polyacrylamide gel. From the films, differentially expressed genes, which were overexpressed or downregulated in various chemicals and $\mathrm{H}_{2} \mathrm{O}_{2}$ treated HUVECs, were identified and were then subcloned into the pGEM-T easy vector with the use of the TA cloning system, and subjected to an automatic sequencing analysis.

\section{Northern blot analysis}

The extracted total RNA of the cells was treated with DNase I and reverse transcribed with random hexamer priming (Clontech). By using the product as template, PCR was performed by using 5'-GTGAGCGCAAAGCCTCAG- $3^{\prime}$ as the sense primer and $5^{\prime}$ TGCATGGTGTATGTCCCTGT-3' as the antisense primer (Sig-1R GenBank accession no. NM_005866). This RT-PCR product size was $840 \mathrm{bp}$. This 840-bp product was used as a probe for Northern blot analysis. Northern blot analysis was carried out, in which $20 \mu \mathrm{g}$ of denatured total RNA was electrophoresed on a $1.0 \%$ formaldehyde agarose gel and transferred to a nylon membrane (Roche Diagnostics $\mathrm{GmbH}$, Mannheim, Germany). Blot was hybridized with the randomly primed $\left.{ }^{32} \mathrm{P}\right]$-labeled $840-\mathrm{bp}$ cDNA probe. Human $\beta$-actin cDNA control probe was used as a loading control.

\section{Cell viability screening with chemical library}

Based on structural similarity compared with meGAL, 14 chemicals showing more than $70 \%$ structural similarity were chosen. These 14 chemicals were kindly provided by Dr. HS Park (Dept. of Chemistry, Yale University). Structural similarity was calculated by ChemFinder (Cambridgesoft, MA). Basically same experimental procedure with previous cell viability assay was used for meGAL-related chemical screening except that the concentration of each chemical and $\mathrm{H}_{2} \mathrm{O}_{2}$ was fixed at $0.02 \mathrm{mM}$ and $0.2 \mathrm{mM}$, respectively. Chemicals were pretreated to HUVECs 
for $1 \mathrm{~h}$ and then cells were incubated with $0.2 \mathrm{mM}$ $\mathrm{H}_{2} \mathrm{O}_{2}$ for $1 \mathrm{~h}$. Less harsh condition $(0.2 \mathrm{mM})$ than 1 $\mathrm{mM}$ of $\mathrm{H}_{2} \mathrm{O}_{2}$ was used to increase selection ratio in this primary screening, which would give more information about the relationship between chemical structures and activities. HUVECs' survival was determined as about $60 \%$ at $0.2 \mathrm{mM} \mathrm{H}_{2} \mathrm{O}_{2}$ treatment. Experiments for each chemical were repeated three times and data were averaged. Viability recovery was calculated as relative recovery ratio, which means differences from cell viability of control. Control is viabilities of cells treated with $\mathrm{H}_{2} \mathrm{O}_{2}$ alone.

\section{Results}

\section{Effects of $\mathrm{H}_{2} \mathrm{O}_{2}$ exposure on HUVECs in cell based assay}

Cell based assay is basically to monitor the change of cell viability induced by oxidative stress, which was $\mathrm{H}_{2} \mathrm{O}_{2}$ exposure on HUVECs in our experiments.

A<smiles>COC(=O)c1cc(O)c(O)c(O)c1</smiles>

B

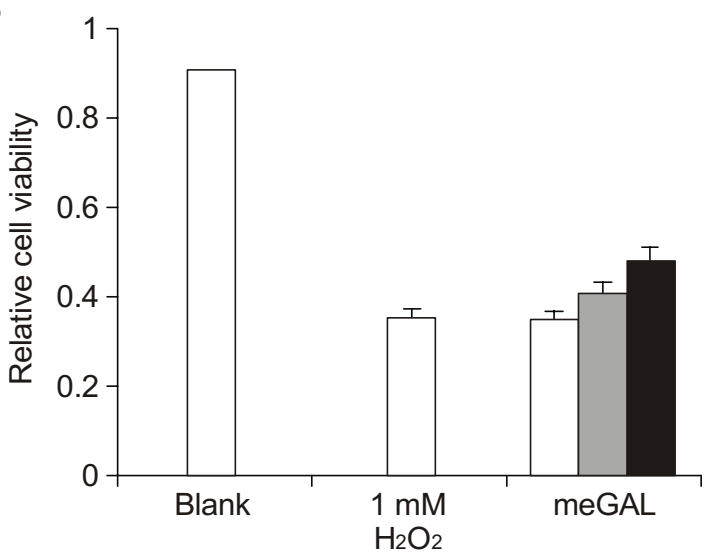

C

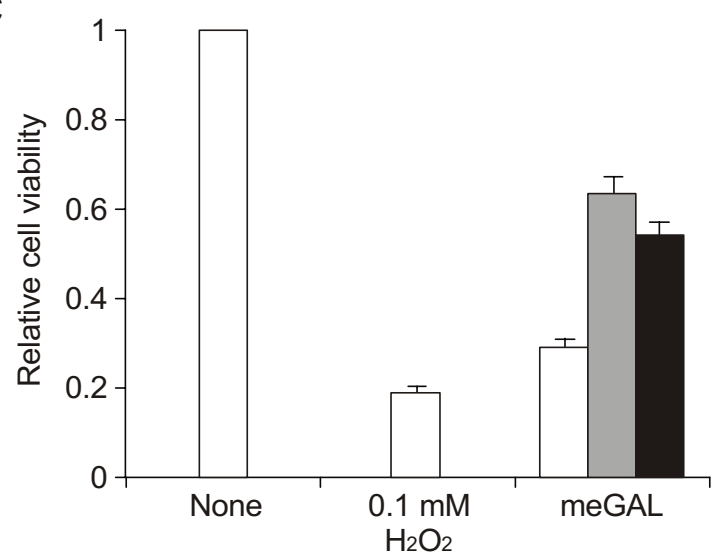

Figure 2. Primary screening of meGAL using cell based assay. (A) The chemical structure of meGAL. Cell viability assay was performed with three different concentrations of meGAL. Prior to incubation with $\mathrm{H}_{2} \mathrm{O}_{2}$, HUVECs were treated with 0.02 (opened bar), 0.1 (scratched bar) and 0.5 (black bar) $\mathrm{mM}$ of each phytochemical for $1 \mathrm{~h}$ and then followed (B) $1 \mathrm{~h}$ incubation in $1 \mathrm{mM} \mathrm{H}_{2} \mathrm{O}_{2}$ and $(\mathrm{C}) 48 \mathrm{~h}$ incubation in $0.1 \mathrm{mM} \mathrm{H}_{2} \mathrm{O}_{2}$. Blank denotes untreated control HUVECs. Data are represented as mean \pm SD. 
Preliminary experiments were performed to determine the effects of $\mathrm{H}_{2} \mathrm{O}_{2}$ exposure on HUVECs (Figure 1). The concentration of $\mathrm{H}_{2} \mathrm{O}_{2}$ was varied from 0.2 to 5 $\mathrm{mM}$ and cell death induced by $\mathrm{H}_{2} \mathrm{O}_{2}$ was monitored. Cell viability was also assessed after $0.5,1$ or $2 \mathrm{~h}$. Cell viability was ranged from $70 \%(0.2 \mathrm{mM})$ to $10 \%$ ( $5 \mathrm{mM}$ ) and $40 \%$ of cells were viable at $1 \mathrm{mM} \mathrm{H}_{2} \mathrm{O}_{2}$ (Figure 1). Therefore, $1 \mathrm{mM} \mathrm{H} \mathrm{O}_{2}$ was used through all subsequent screenings to differentiate the effects of survival and death by meGAL.

\section{Primary screening of meGAL using cell based assay}

meGAL was extracted, purified and used as a primary screening material (Figure 2A). Since cell based assay is more direct assay to select antioxidative chemicals, it was employed as primary screening assay. Three different concentrations $(0.02,0.1$, and $0.5 \mathrm{mM}$ ) of meGAL were treated for $1 \mathrm{~h}$ prior to the addition of $1 \mathrm{mM} \mathrm{H}_{2} \mathrm{O}_{2}$ and relative cell viabilities in comparison to HUVECs alone were monitored (Figure $2 \mathrm{~B})$. In addition to high concentration of $\mathrm{H}_{2} \mathrm{O}_{2}$ treatment $(1 \mathrm{mM})$, low concentration of $\mathrm{H}_{2} \mathrm{O}_{2}(0.1 \mathrm{mM})$ was introduced on HUVECs for $48 \mathrm{~h}$ to evaluate meGAL that may protect cells exposed to $\mathrm{H}_{2} \mathrm{O}_{2}$ at low concentration and for $48 \mathrm{~h}$ (Figure 2C). meGAL improved cell survival rate at $0.1 \mathrm{mM}$ and $0.5 \mathrm{mM}$ concentrations, respectively (Figures $2 \mathrm{~B}$ and $2 \mathrm{C}$ ). Especially, for long exposure and at low concentration of $\mathrm{H}_{2} \mathrm{O}_{2}(0.1 \mathrm{mM}, 48 \mathrm{~h})$, meGAL enhanced the viability of HUVECs up to about $60 \%$ (Figure 2C) when compared with the survival rate of HUVECs exposed to $1 \mathrm{mM} \mathrm{H}_{2} \mathrm{O}_{2}$ for $1 \mathrm{~h}(40 \%)$ or exposed to $0.1 \mathrm{mM}$ $\mathrm{H}_{2} \mathrm{O}_{2}$ for $48 \mathrm{~h}(20 \%)$.

\section{SOD and CAT assays}

In the present experiment, $\mathrm{H}_{2} \mathrm{O}_{2}$ exposure on HUVECs resulted in no significant change in either CAT or SOD activities in HUVEcs and meGAL also did not affect activities of both enzymes in HUVECs (data not shown).

\section{LPO assay and intracellular $\mathrm{H}_{2} \mathrm{O}_{2}$ determination}

MDA level obtained from meGAL treatment on HUVECs alone was similar to the level in the HUVEC cultures without oxidative stress (Figure $3 \mathrm{~A}$ ). When the cells are treated with $\mathrm{H}_{2} \mathrm{O}_{2}$, however, there was a significant increase of MDA production to about $210 \%$ $(P=0.0317)$. This elevated MDA level was decreased to $180 \%$ with treatment of meGAL prior to the addition of $\mathrm{H}_{2} \mathrm{O}_{2}$ (Figure $3 \mathrm{~A}$ ).

To address the possibility that the increased cell viability in the presence of phytochemicals is due to decreased production of ROS inside cells, we measured intracellular concentrations of $\mathrm{H}_{2} \mathrm{O}_{2}$ in HUVECs. The effect of meGAL on cellular oxidation was determined by DCF fluorescence. HUVECs activated by $\mathrm{H}_{2} \mathrm{O}_{2}$ showed an increase in free radical level by about $55 \%$ over non-treated HUVECs (Figure 3B). Pretreatment with meGAL prior to the addition of $\mathrm{H}_{2} \mathrm{O}_{2}$ decreased intracellular $\mathrm{H}_{2} \mathrm{O}_{2}$ levels to $24 \%$ (Figure 3B). Since meGAL showed high ROS scavenging effect, direct scavenging of ROS by meGAL could account for reduced intracellular $\mathrm{H}_{2} \mathrm{O}_{2}$.

\section{Free radical scavenging activity}

meGAL exposure on HUVECs showed very high free radical scavenging activity at low concentrations
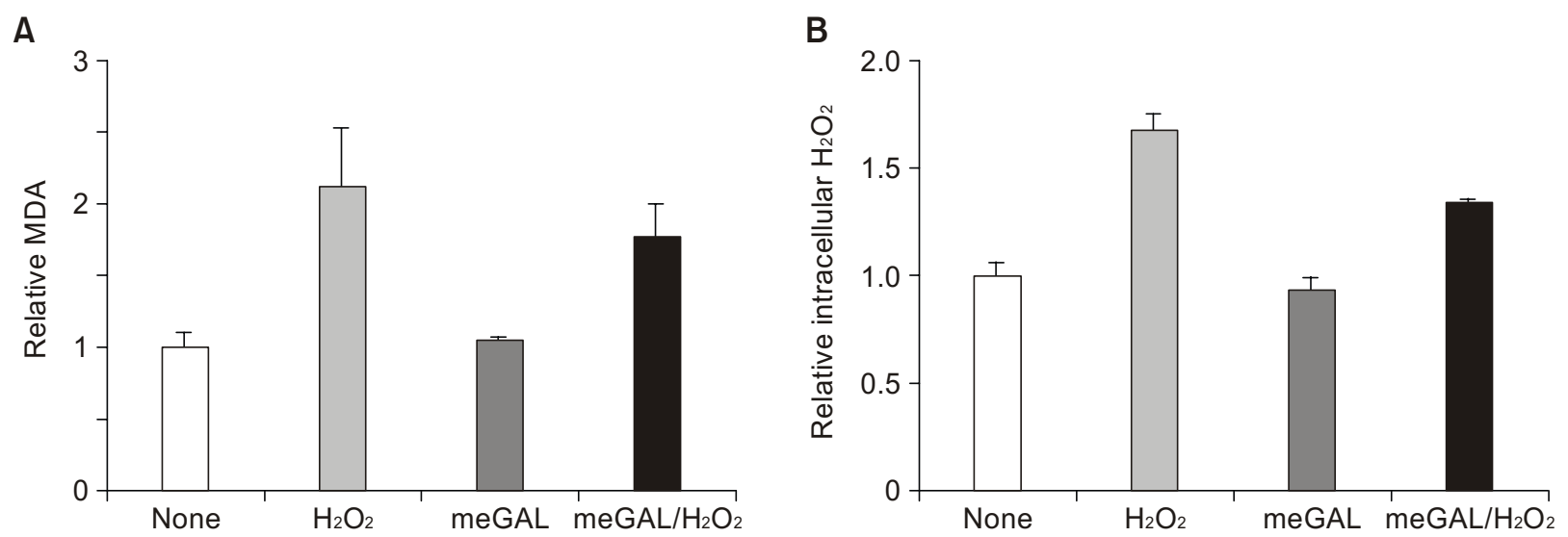

Figure 3. Intracellular LPO production and $\mathrm{H}_{2} \mathrm{O}_{2}$ determination. (A) $\mathrm{LPO}$ production of HUVECs with the treatment with $\mathrm{H}_{2} \mathrm{O}_{2}$ and/or meGAL. $P=0.0317$ by one-sided $t$-test with normalized values. (B) Intracellular $\mathrm{H}_{2} \mathrm{O}_{2}$ determination by DCF with the treatment with $\mathrm{H}_{2} \mathrm{O}_{2}$ and/or meGAL for $1 \mathrm{~h}$. Each value is the means $\pm S D$ of three independent experiments. 

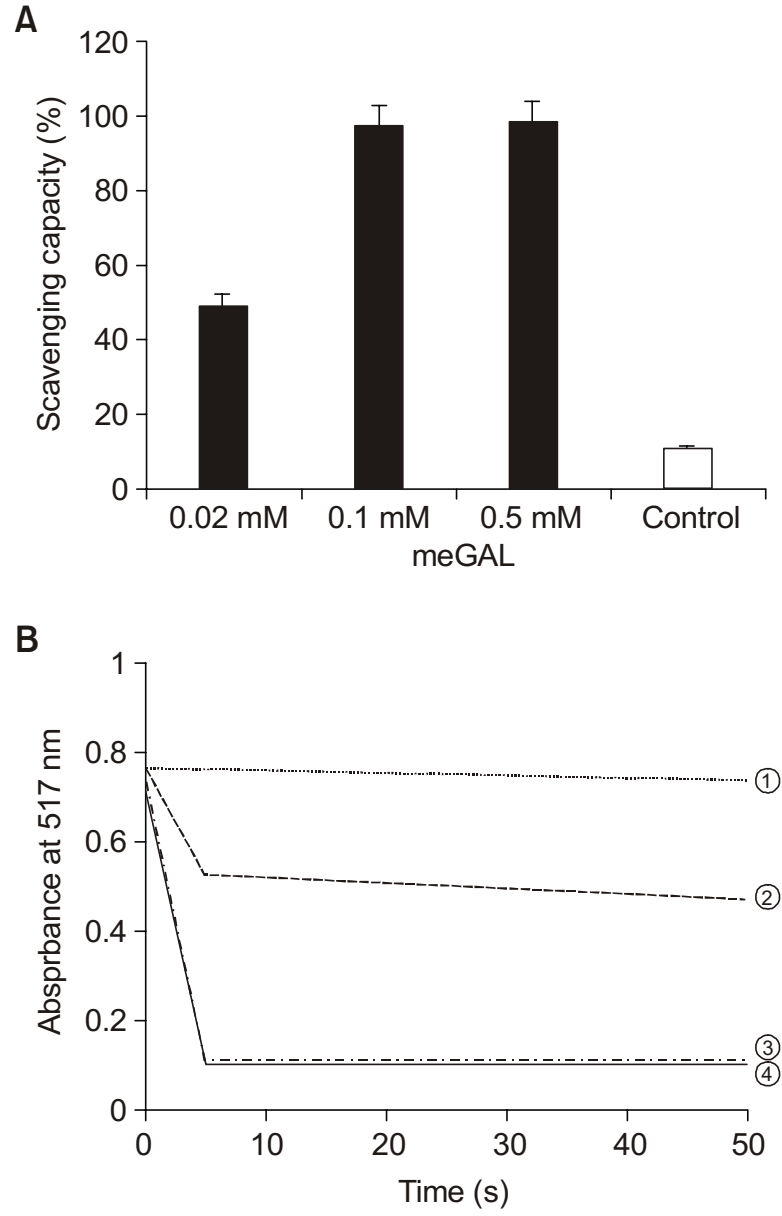

Figure 4. Free radical scavenging activity and scavenging kinetics of meGAL. (A) Free radical scavenging ability of meGAL determined by using DPPH assay. $80 \mu \mathrm{M}$ of DPPH solution in ethanol was prepared and added to various concentrations of chemical $(0.02,0.1$ and $0.5 \mathrm{mM})$ in ethanol. Absorbance changes at $517 \mathrm{~nm}$ for $10 \mathrm{~min}$ with $10 \mathrm{~s}$ of interval were monitored. Each value is the means $\pm S D$ of three independent experiments. (B) Time dependent free radical scavenging by meGAL. After mixing DPPH and meGAL, with $5 \mathrm{~s}$ intervals absorbance at 517 $\mathrm{nm}$ was monitored. DPPH alone ( (1)), with $0.02 \mathrm{mM}$ ( (2) ), 0.1 $\mathrm{mM}$ ( (3) ), $0.5 \mathrm{mM}$ of meGAL ( (4) ).

(Figure $4 \mathrm{~A}$ ). At $0.02 \mathrm{mM}$ of meGAL, $50 \%$ of free radicals were quenched and over $0.1 \mathrm{mM}$, free radical scavenging was saturated. In terms of scavenging kinetics, free radical scavenging by meGAL was immediate. Within $5 \mathrm{~s}$, more than $90 \%$ of free radicals were scavenged at $0.02 \mathrm{mM}$ of meGAL exposure on HUVECs (Figure 4B). Consequently, free radical scavenging ability of meGAL was fast and efficient at used concentrations, which may contribute on the cell protective ability of meGAL against oxidative stress.

\section{Differential display and Northern blot analysis}

Using the DDRT-PCR, genomic expression levels in

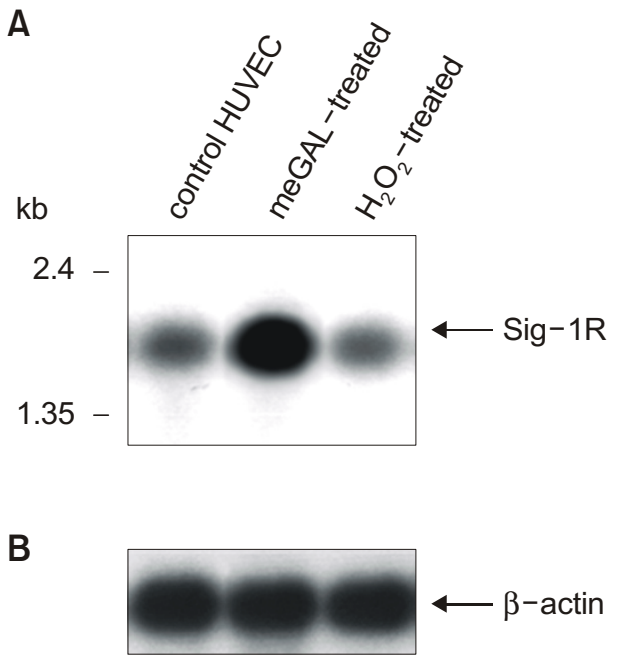

Figure 5. Sig-1R gene expressions in HUVECs. Northern blot analysis was performed to determine the expression pattern in HUVECs. Blot was hybridized with the randomly primed $\left.{ }^{32} \mathrm{P}\right]$-labeled 840-bp cDNA probe. Human $\beta$-actin cDNA control probe was used as a loading control.

Table 1. Patterns of differentially expressed genes by meGAL or $\mathrm{H}_{2} \mathrm{O}_{2}$.

\begin{tabular}{|c|c|}
\hline Expression & Con \\
\hline Control meGAL $\mathrm{H}_{2} \mathrm{O}_{2}$ & Gene \\
\hline Weak Strong Weak & Type I Sigma receptor (Sig-1R) \\
\hline Weak Medium Weak & Chromosome condensation 1 (RCC1) \\
\hline Weak Medium Weak & Phosphate carrier \\
\hline
\end{tabular}

HUVECs were estimated after $\mathrm{H}_{2} \mathrm{O}_{2}$ exposure or meGAL treatment, respectively. Differentially expressed mRNAs by meGAL or $\mathrm{H}_{2} \mathrm{O}_{2}$ treatment were selected and compared to each other. Among identified genes, the change of gene expression pattern by meGAL in comparison to untreated HUVECs was interesting and unique. meGAL upregulated various membrane receptor gene expressions including regulator of chromatin condensation 1 (RCC1), type 1 sigma receptor (Sig-1R) and phosphate carrier protein (PiC) (Table 1). Among three identified genes, RCC1, Sig-1R and PiC, by using the DDRT-PCR, Sig-1R showed the most strong upregulation after treatment with meGAL compared with RCC1 or PiC (Table 1). Accordingly we performed Northern blot analysis to reconfirm the upregulation of Sig-1R in meGAL-treated HUVECs. As expected, Sig-1R was upregulatedd in meGAL-treated HUVECs compared to control HUVECs or $\mathrm{H}_{2} \mathrm{O}_{2}$-treated HUVECs (Figure 5). 
Table 2. Screening results of meGAL-related chemical library.

\begin{tabular}{|c|c|c|c|c|c|c|c|}
\hline $\begin{array}{l}\text { No. of } \\
\text { chemical }\end{array}$ & Structure & Name & $\begin{array}{c}\text { Survival }^{a} \\
(\%)\end{array}$ & $\begin{array}{c}\text { No. of } \\
\text { chemical }\end{array}$ & Structure & Name & $\begin{array}{c}\text { Survival }^{a} \\
(\%)\end{array}$ \\
\hline 1 & & $\begin{array}{l}\text { EVERNINIC } \\
\text { ACID }\end{array}$ & 12.6 & 9 & & $\begin{array}{l}\text { GENETISIC } \\
\text { ACID }\end{array}$ & 15.9 \\
\hline 2 & & $\begin{array}{l}\text { METHYLORSE } \\
\text { LLINIC ACID, } \\
\text { ETHYL ESTER }\end{array}$ & 23.7 & 10 & & $\begin{array}{l}\text { SODIUM } p- \\
\text { AMINOSALIC } \\
\text { YLATE }\end{array}$ & 16.8 \\
\hline 3 & & GALLIC ACID & 35.0 & 11 & & ASPIRIN & 5.9 \\
\hline 4 & & $\begin{array}{l}\text { HAEMATOMMIC } \\
\text { ACID, } \\
\text { ETHYL ESTER }\end{array}$ & 56.2 & 12 & & BENZOCAINE & 11.7 \\
\hline 5 & & SYRINGIC ACID & 20.8 & 13 & & $\begin{array}{l}\text { BENZYL } \\
\text { BENZOATE }\end{array}$ & 7.5 \\
\hline 6 & & OBLIQUIN & 10.5 & 14 & & DIPYROCETYL & 5.9 \\
\hline 7 & & ATRANORIN & 13.0 & meGAL & & Methyl gallate & 18.1 \\
\hline 8 & & FRAXETIN & 11.7 & & & & \\
\hline
\end{tabular}

${ }^{a}$ Survival: relative survival ratio (\%) to control.

\section{Cell viability assay with chemicals structurally related to meGAL}

Based on structural similarity compared with meGAL, 14 chemicals showing more than $70 \%$ structural similarity were chosen and previous cell viability assay was used for meGAL-related chemical screening (Table 2). To determine the cell viability, XTT assay was used as described. Through viability assay, four chemicals related to meGAL showed more than $20 \%$ enhancement of viability in comparison with control (Table 2). Four chemicals related to meGAL were methylorsellinic acid ethyl ester (chemical No. 2, 23.7\% enhancement of viability), gallic acid (chemical No. 3, 35.0\% enhancement of viability), haematommic acid ethyl ester (chemical No. $4,56.2 \%$ enhancement of viability) and syringic acid (chemical No. 5, 20.8\% enhancement of viability). Percentages in parenthesis indicate the relative viability enhancement. Experiments for each chemical were repeated three times and data were averaged. Haematommic acid ethyl ester showed the highest activity among tested 14 chemicals. These 4 chemicals were selected as primary hits since those were considered as chemicals showing significant enhancement of viability in comparison with meGAL, which showed only $18.1 \%$ enhancement of cell viability.

\section{Discussion}

Reducing reactive oxygen species in the body is one of main efforts towards protection of various diseases such as aging process, cancer, diabetes and neurodegenerative diseases (Hsieh et al., 2004). Many natural products including flavonoids, cumarins, polyols have been studied for the characterization and the development as antioxidative reagents (Finkel and Holbrook, 2000; Lee et al., 2002).

In our studies, meGAL, a polyphenol derivative, showed protective effects against $\mathrm{H}_{2} \mathrm{O}_{2}$-mediated oxidative stress. Very efficient radical scavenging ability of meGAL clearly explains the protective effect 
against oxidative stress. Especially for the long term exposure $(48 \mathrm{~h})$ at low concentration $(0.1 \mathrm{mM})$ of $\mathrm{H}_{2} \mathrm{O}_{2}$, meGAL was very effective. While meGAL did not affect the biological activities involved in antioxidative mechanisms such as CAT and SOD in the biological systems, induced lipid peroxidation and internal ROS level by $\mathrm{H}_{2} \mathrm{O}_{2}$ in the HUVECs were significantly reduced by meGAL treatment. From these results, $\mathrm{H}_{2} \mathrm{O}_{2}$ scavenging effect probably is primary reason for the protective effect of meGAL from $\mathrm{H}_{2} \mathrm{O}_{2}$-mediated oxidative stress.

To find out more efficient antioxidants from the meGAL derivatives, 14 chemicals showing more than $70 \%$ structural similarity with meGAL were chosen and cell viability assay was used for meGAL-related chemical screening. Through viability assay, four chemicals related to meGAL showed more than $20 \%$ enhancement of viability in comparison with control. Four chemicals related to meGAL were methylorsellinic acid ethyl ester, gallic acid, haematommic acid ethyl ester and syringic acid. Haematommic acid ethyl ester showed the highest enhancement of cell viability (56.2\%) among tested 14 chemicals.

Methylorsellinic acid is the precursor of mycophenolic acid which is the active compound formed following the administration of the pro-drug mycophenolate mofetil (Puel et al., 2005). Mycophenolic acid is an antibiotic useful in research for the selection of animal cells that express the $E$. coli gene coding for xanthine guanine phosphoribosyltransferase and is also used as immunosuppressive agent. Plant phenolic, which form moieties on flavonoid rings, such as gallic acid, is widely consumed. Several beneficial properties have been attributed to this dietary compound, including antioxidant, anti-inflammatory, and anticarcinogenic effects (Galati and O'Brien, 2004). Phenolic compounds, hematommic acid and syringic acid, protect brain against lipid peroxidation (Toledo Marante et al., 2003) and show antioxidant activity (Kalkan Yildirim et al., 2004), respectively. These 4 chemicals were selected as primary hits since those were considered as chemicals showing significant enhancement of viability in comparison with meGAL. Further investigation would be necessary to optimize its activity and drug-likeness for the development as a drug candidate.

To link the evidences of antioxidative ability of meGAL to molecular mechanisms, the analysis of gene expression patterns by differential display method was carried out. Our results suggest alternative mechanisms for the antioxidative effects of meGAL. Upregulated genes by meGAL were RCC1, Sig-1R and PiC. RCC1 is known to be involved in cell cycle, cell proliferation, nuclear transport and the inhibition of the Ran-GEF activity of RCC1 was reported to cause cell death through premature chromatin con- densation (Nishijima et al., 2003; Zheng, 2004). Sig-1R also has the variety of functions such as a novel opioid receptor, cellular proliferation and modulations of ion channel, ankyrin, $\mathrm{Ca}^{2+}$ and sphingolipid levels (Hayashi and Su, 2001; Aydar et al., 2004; Spruce et al., 2004). Similar to RCC1, small molecule antagonists of Sig-1R inhibit tumor cell survival by activating programmed cell death (Zheng, 2004). The fact that inhibitors of RCC1 and Sig-1R induce cancer cell death through various mechanisms suggests that RCC1 and Sig-1R may play important roles in maintaining cell viability. Especially, Sig-1R involved in calcium flux supports its role in cell survival against oxidative stress. Oxidative stress mediated increase in the cytosolic calcium concentration contributes to the activation of PKC-alpha (Larsson and Cerutti, 1989) and to the transcriptional induction of the AP-1, of which pathway has been known as apoptotic process (Droge, 2002). In a recent report, it has been shown that Sig-1R prevents the rise in intracellular calcium concentration and consequently controls PLC activity. In addition to the calcium regulation, antagonists of Sig-1R inhibit the activity of PKB/Akt in an apparently calcium-independent manner. Thus, PLC activation and PKB/Akt inhibition in response to Sig-1R antagonists appear to constitute biochemically separable signal transduction responses, which are to restrain the proapoptotic signaling pathway and to stimulate a prosurvival signaling cascade (Spruce et al., 2004). Based on these results that Sig-1R regulates apoptosis and survival signaling pathways for the cell survival, cellular protective ability of meGAL against oxidative stress may be linked to the induction of Sig-1R gene by meGAL.

These results suggest that meGAL-induced genes may play roles in cellular protective functions of meGAL. Further investigation with identified genes is intensively undergoing to support this preliminary linkage between anti-oxidative activities and molecular mechanisms involved in meGAL-mediated cell survival. This study suggests that meGAL and meGALrelated chemicals protect HUVECs from oxidative stress.

\section{Acknowledgement}

This study was supported by a grant of the Korea Health 21 R\&D Project, Ministry of Health \& Welfare, Republic of Korea (02-PJ10-PG6-AG01-0003).

\section{References}

Adler V, Yin Z, Fuchs SY, Nenezra M, Rosario L, Tew KD, Pincus MR, Sardana M, Henderson CJ, Wolf CR, Davis RJ, Ronai, Z. Regulation of JNK signaling by GSTp. EMBO J 1999;18:1321-34 
Aydar E, Palmer CP, Djamgoz MBA. Sigma receptors and cancer: possible involvement of ion channels. Cancer Res 2004;64: 5029-35

Beckman KB, Ames BN. The free radical theory of aging matures. Physiol Rev 1998;78:547-81

Chen A, Zhang L. The antioxidant (-)-epigallocatechin-3gallate inhibits rat hepatic stellate cell proliferation in vitro by blocking the tyrosine phosphorylation and reducing the gene expression of platelet-derived growth factor- $\alpha$ receptor. J Biol Chem 2003; 278:23381-9

Cho EJ, Yokozawa T, Rhyu DY, Kim SC, Shibahara N, Park JC. Study on the inhibitory effects of Korean medicinal plants and their main compounds on the 1,1-diphenyl-2-picrylhydrazyl radical. Phytomedicine 2003;10:544-51

Cho EJ, Yokozawa T, Kim HY, Shibahara N, Park JC. Rosa rugosa attenuates diabetic oxidative stress in rats with streptozotocin-induced diabetes. Am J Chinese Med 2004; 32:487-96

Curtin JF, Donovan M, Cotter T. Regulation and measurement of oxidative stress in apoptosis. J Immunol Methods 2002; 265:49-72

Droge W. Free radicals in the physiological control of cell function. Physiol Rev 2002;82:47-95

Estrada-Garcia L, Carrera-Rotllan J, Puig-Parellada P. Effects of oxidative stress and antioxidant treatments on eicosanoid synthesis and lipid peroxidation in long term humaan umbilical vein endotherial cells culture. Prostaglandins Other Lipid Mediat. 2002;67:13-25

Finkel T, Holbrook NJ. Oxidants, oxidative stress and the biology of aging. Nature 2000;408:239-47

Galati G, O'Brien PJ. Potential toxicity of flavonoids and other dietary phenolics: significance for their chemopreventive and anticancer properties. Free Radic Biol Med 2004;37:287-303

Galato D, Ckless K, Susin MF, Giacomelli C, Ribeirodo-Valle RM, Spinelli A. Antioxidant capacity of phenolic and related compounds: correlation among electrochemical, visible spectroscopy methods and structure-antioxidant activity. Redox Rep 2001;6:243-50

Hayashi T, Su T. Regulating ankyrin dynamics: Roles of sigma-1 receptors. Proc Natl Acad Sci USA 2001;98:491-6

Hsieh T, Liu T, Chia Y, Chern C, Lue F, Chuang M, Mau S, Chen S, Syu Y, Chen C. Protective effect of methyl gallate from Toona sinensis (Meliaceae) against hydrogen peroxide-induced oxidative stress and DNA damage in MDCK cells. Food Chem Toxicol 2004;42:843-50

Kalkan Yildirim H, Delen Akcay Y, Guvenc U, Yildirim Sozmen E. Protection capacity against low-density lipoprotein oxidation and antioxidant potential of some organic and non-organic wines. Int J Food Sci Nutr 2004;55:351-62

Kizu H, Tomimori T. Phenolic constituents from the flowers of Nymphaea stellata. Natural Medicines 2003;57:118

Larsson R, Cerutti P. Translocation and enhancement of phosphotransferase activity of protein kinase $c$ following exposure in mouse epidermal cells to oxidants. Cancer Res
$1989 ; 49: 5627-32$

Lee SE, Ju EM, Kim JH. Antioxidant activity of extracts from Euryale ferox seed. Exp Mol Med 2002;34:100-6

Liang $\mathrm{P}$, Pardee AB. Differential display of eukaryotic messenger RNA by means of the polymerase chain reaction. Science 1992;257:967-71

Lim MY, Park YH, Son DJ, Kim MK, Lee HS. Antiplatelet activity of gallic acid and methyl gallate. Food Sci Biot 2004; 13:806-9

Nakamura $\mathrm{H}$, Matuda M, Furuke K, Iwata S, Toda K, Inamoto T, Yamaoka Y, Ozawa K, Yodoi J. Adult T cell leukemia-derived factor/human thioredoxin protects endotherial F-2 cell injury caused by activated neorophils or hydrogen peroxide. Immunol Lett 1994;42:75-80

Nishijima $H$, Nishitani $H$, Saito $N$, Nishimoto T. Caffeine mimics adenine and 2'-deoxyadenosine, both of which inhibit the guanine-nucleotide exchange activity of RCC1 and the kinase activity of ATR. Genes Cells 2003;8:423-35

Puel O, Tadrist S, Galtier P, Oswald IP, Delaforge M. Byssochlamys nivea as a source of mycophenolic acid. Appl Environ Microbiol 2005;71:550-3

Sciuto AM, Moran TS. Effect of dietary treatment with n-propyl gallate or vitamin $E$ on the survival of mice exposed to phosgene. J Appl Toxicol 2001;21:33-9

Shuli S, Heintz NH, Periasamy M, Manohar M, Janssen YM, Marsh JP, Mossaman BT. Differential regulation of antioxidant enzymes in response to oxidants. J Biol Chem 1991;266: 24398-403

Sies $\mathrm{H}$. Strategies of antioxidant defense. Eur J Biochem 1993;215:213-9

Sohi KK, Mittal N, Hundal MK, Khanduja KL. Gallic acid, an antioxidant, exhibits antiapoptotic potential in normal human lymphocytes: A Bcl-2 independent mechanism. J Nutr Sci Vitaminol 2003;49:221-7

Spruce BA, Campbell LA, McTavish N, Cooper MA, Appleyard VL, O'Neill M, Howie J, Samson J, Watt S, Murray $K$, McLean D, Leslie NR, Safrany ST, Ferguson MJ, Peters JA, Prescott AR, Box G, Hayes A, Nutley B, Raynaud F, Downes CP, Lambert JJ, Thompson AM, Eccles S. Small molecule antagonists of the $\sigma-1$ receptor cause selective release of the death program in tumor and self-reliant cells and inhibit tumor growth in vitro and in vivo. Cancer Res 2004;64:4875-86

Toledo Marante FJ, Garcia Castellano A, Estevez Rosas F, Quintana Aguiar J, Bermejo Barrera J. Identification and quantitation of allelochemicals from the lichen Lethariella canariensis: phytotoxicity and antioxidative activity. J Chem Ecol 2003;29:2049-71

Valen G, Sonden A, Vaage J, Malm E, Kjellstrom T. Hydrogen peroxide induces endotherial cell atypia and cytoskeleton deplymerization. Free Radic Biol Med 1999;26: 1480-8

Waxman A, Mahboubi K, Knickelbein RG, Mantell LL, Manzo $\mathrm{N}$, Pober JS, Elias JA. Interleukin-11 and interleukin-6 protect cultured human endothelial cells from $\mathrm{H}_{2} \mathrm{O}_{2}$.induced 
cell death. Am J Respir Cell Mol Biol 2003;29:513-22

Westenburg HE, Lee KJ, Lee SK, Fong $\mathrm{HH}$, van Breemen $\mathrm{RB}$, Pezzuto JM, Kinghorn AD. Activity-guided isolation of antioxidative constituents of Cotinus coggygria. J Nat Prod 2000;63:1696-8

Zapolska-Downar D, Zapolska-Downar A, Bukowska H, Galka $\mathrm{H}$, Naruszewicz M. Ibuprofen protects low density lipo- proteins against oxidative modification. Life Sci 1999;65: 2289- 303

Zhang M, Storz G. Redox sensing by prokaryotic transcription factors. Biochem Pharmacol 2000;59:1-6

Zheng Y. G protein control of microtubule assembly. Annu Rev Cell Dev Biol 2004;20:867-94 